\title{
The Impact of Total Foreign Debt on the Economic Growth of Egypt (1980-2018)
}

\author{
Alaa Safwat ${ }^{*}$, Ashraf Salah ${ }^{2}$, Marwa El Sherif ${ }^{1}$ \\ ${ }^{1}$ Finance Department, College of Management and Technology, Arab Academy for Science and Technology, Giza, Egypt \\ ${ }^{2}$ Finance Department, College of Management and Technology, Arab Academy for Science and Technology, Alexandria, Egypt \\ Email: *allms@aast.edu
}

How to cite this paper: Safwat, A., Salah, A., \& El Sherif, M. (2021). The Impact of Total Foreign Debt on the Economic Growth of Egypt (1980-2018). Open Journal of Social Sciences, 9, 130-151.

https://doi.org/10.4236/jss.2021.910010

Received: September 13, 2021

Accepted: October 17, 2021

Published: October 20, 2021

Copyright (c) 2021 by author(s) and Scientific Research Publishing Inc. This work is licensed under the Creative Commons Attribution International License (CC BY 4.0).

http://creativecommons.org/licenses/by/4.0/ (c) (i) Open Access

\begin{abstract}
Foreign debt is considered to be a source of income for countries. If foreign debt is managed well and directed towards productive projects, then it might enhance the countries' economic growth. However, foreign debt has many costs that might cause deterioration in the economy. This study aims to investigate how total foreign debt impacts the economic growth of Egypt for a time period of 39 years (1980-2018). In the methodology, descriptive statistics, unit root tests, Johansen co-integration and Vector Error Correction Model (VECM) are used. The results show that total foreign debt exerts a significant long run negative impact on the Egyptian economic growth, while the results are insignificant in the short run.
\end{abstract}

\section{Keywords}

Total Foreign Debt, Economic Growth, Johansen Co-Integration, VECM

\section{Introduction}

One of the most significant goals for developing countries is achieving high economic growth. However, due to the insufficiency of capital for the purpose of investing domestically, developing countries are forced to borrow from external sources. By utilizing the external debt towards effective projects, economic growth could be achieved (Todaro \& Smith, 2006).

Foreign debt means debt owed to governmental securities' holders such as treasury bonds, bills and notes. Governments in general borrow to pay off other debt that is matured or to fill the gap between low revenues and high expenditures (Babu, Kiprop, Kalio, \& Gisore, 2015). External debt has many advantages and disadvantages. Among the advantages, it is using the external debt to finance viable projects that need capital which is not available through domestic 
sources. These viable projects might be in the form developing rural and urban areas, enhancing the tourism activities, investing in agriculture, mineral exploration, and improving the transportation and communication infrastructures (Osuagwu \& Orbunde, 2015). Furthermore, external debt might be used in investing in technology and buying equipment to further support production process. This would help developing countries foster their production levels and thus enhance their economic growth. In addition, foreign debt could be used as an emergency income for governments in cases of war or any other unplanned situation such as natural disasters where a lack in tax revenues might exist (Weiss, 2007). These unexpected events deteriorate the economy and thus the role of foreign debt comes in the form of financial flows used to help the economy to recover faster (Saylor \& Wheeler, 2017). Another advantage of using foreign debt especially when it is dominated by foreign currency such as US dollar or euro, is its abundance compared to domestic currencies. As a result, the pressure on domestic financing sources would be relieved and more investments would be facilitated and thus the economy would be improved smoothly (Brkić, 2021).

However, interest needed to be paid on the foreign debt is the main disadvantage. Governments try to raise the level of taxes or shift the usage of revenues from productive projects towards the foreign debt payments which adversely affects their economic growth (Lin \& Sosin, 2001). Despite the fact that foreign debt is considered to be a very important source of income for developing countries, external debt burden might cause major problems for them (Forgha, Mbella, \& Ngangnchi, 2014). Another significant disadvantage of using foreign debt especially when it is denominated in foreign currency and unhedged as well, is exposing the borrower to fluctuations in the exchange rate. When governments obtain tax revenues in domestic currency, while borrowing in foreign currency, this would expose the domestic currency to potential depreciation. One of the major reasons behind domestic currency depreciation is the situation where foreign investors liquidate their positions in government bonds or when creditors call back their loans suddenly which would exert a downward pressure on the domestic currency. As a result, both the ratio of debt to GDP and interest value (in domestic currency) would increase which affects the budget balance and the whole economy adversely. Furthermore, not only governments that borrow in a foreign currency suffer from exchange rate fluctuations, but also the creditors suffer as the ability of governments to repay the debt decreases when the domestic currency depreciates. As a result, if creditors are no longer interested to finance the government, and if a large amount of obligations should be paid in a short time, then a debt and currency crisis might occur (Brkić, 2021).

Since a debate exists for how foreign debt impacts the economic growth of countries, as it has benefits as well as costs, then this study aims to investigate the impact of total foreign debt on the Egyptian economic growth for a time period of 39 years ranging from 1980 till 2018. 


\section{Total Foreign Debt in Egypt}

Figure 1 shows the trend of total foreign debt in Egypt since 1980 till 2018.

As shown in the above figure, the general trend of total foreign debt in Egypt from 1980 till 2018 is increasing. However, some periods witnessed a drop in the external debt which is explained in the following paragraph.

Alissa (2007) mentioned that after applying the open door policy in 1970, Egypt was using short term debt as a method of finance at a very high cost. In the period from 1973 to 1976, the US imports of wheat had increased four times which in turn affected other countries such as Egypt, where a sharp fall in exports and higher imports existed. After that, the external debt in Egypt at the end of 1981 increased to more than $100 \%$ of its gross national product which put the economy in an unstable position. In addition, the oil crash prices 1985-1986 caused a fiscal deficit followed by higher levels of debt. As a result, the government used an expansionary monetary policy and constrained the use of foreign debt where a decline in total foreign debt till 1991 occurred. The Economic Reform and Structural Adjustment Program (ERSAP) initiated in the 1990s provided stability and maintained the level of external debt in Egypt (Hanafy, 2015). CBE (2003) stated that the external debt in Egypt remained stable but it increased slightly in 2003 by US $\$ 86.7$ million due to the appreciation of many different borrowing currencies versus the US dollar. On the other hand, a decrease in the gross foreign debt to GDP in Egypt from approximately $28.8 \%$ in the financial year 2005-2006 to $20.9 \%$ in the financial year 2007-2008 was attributed to many changes such as a sudden increase in inflation which caused a decline in the Egyptian fiscal revenue and caused a decline in the value of debt (Favaro, Garrido, \& Stucka, 2009). Abdou and Zaazou (2018) mentioned that after the 2011 revolution, Egypt was trying to recover but its foreign debt increased

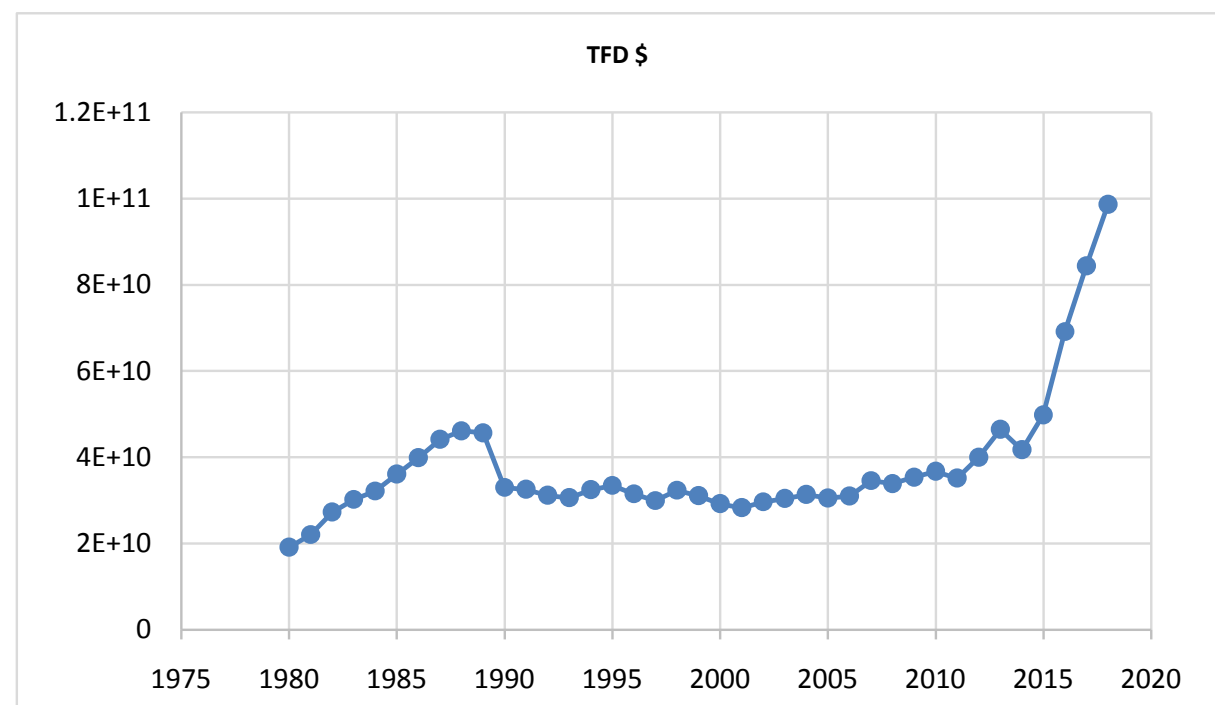

Figure 1. Total foreign debt in Egypt. Source: Author's computation using Microsoft Excel software version 2013. 
continuously from $12.4 \%$ to GDP till it reached $79 \%$ in 2016 . In addition, it continued to increase from 2017 to 2018 by $17.2 \%$ and from 2018 to 2019 by $17.3 \%$ (CBE, 2018; CBE, 2019).

\section{Literature Review}

The effect of foreign debt can vary from developed to developing countries. Developed countries can manage the usage of foreign debt efficiently and productively by utilizing it in added value projects and thus avoiding the risks attached to debt such as high costs of borrowing (high interest rates), volatility of the market, unattractive countries for investment and devaluation of the domestic currency which in turn will affect the countries' economic growth positively. On the other hand, developing countries are not utilizing foreign debt in a productive way which in turn affects their economic growth negatively. This might happen especially when external borrowing is more than $90 \%$ of the GDP (Presbitero, 2012).

Foreign debt's adverse effect on the countries' economic growth might be attributed to the following: Debt Overhang Hypothesis, Crowding Effect, Liquidity Constraint Hypothesis, Direct Effect of Debt Hypothesis and Debt Laffer Curve Theory. Debt Overhang Hypothesis (DPH) means that the high cost of debt prohibits countries from fully benefiting from the value of debt and discourages investment (Borensztein, 1990). Using debt discourages investors from investing because they expect to pay high levels of tax rates on their return to offset the debt burden. Also, investors expect that debt might cause devaluation for the domestic currency and high levels of inflation (Claessens, Detragiache, Kanbur, \& Wickham, 1996). The second negative effect mentioned is the Crowding Effect, which means that governments exert their efforts toward the repayment of debt which in turn adversely affects the other duties of government such as expenditures on public services such as education and health that are essential for economic growth. The third effect is Liquidity Constraint Hypothesis (LCH) which means that countries need foreign exchange in order to repay their debt especially when the country's domestic currency is not used in the international markets. Therefore, countries restrict imports and devalue the domestic currency to encourage the flow of foreign exchange into the economy (Serieux \& Yiagadeesen, 2001). The fourth effect is Direct Effect of Debt Hypothesis (DEDH) which means that foreign debt does not have negative effect on investment and saving function only, but also it adversely affects the mix of factors of production productivity and investment. Investors become uncertain towards investment when the levels of debt are high and thus devote their investments toward short term rather long term projects which in turn affects the economic growth negatively (Pattillo, Poirson, Ricci, Kraay, \& Rigobon, 2003). The fifth and final effect is the Debt Laffer Curve Theory which indicates that external borrowing might help to fill the gap that exists in the government budget (budget deficit) but if it increased over a specific level it will cause repayment burden which will stifle economic growth (Pattillo, Poirson, \& Ricci, 2002). 
Al Kharusi and Ada (2018) studied how Oman's economic growth is influenced by using external debt. Recently, Oman is using higher levels of debt as a result of decreasing the governmental revenues after the decline in oil prices that occurred. In 2016, Oman's foreign debt increased to be $26 \%$ of the GDP and in 2017 it was rated by S\&P as BB credit rating. As a result, it was suggested that any additional increase in foreign debt might cause a financial crisis and thus unstable economy. Higher levels of debt have disadvantages such as crowding effect which means that higher levels of debt reflect higher interest rates and thus higher borrowing costs which makes both consumption and investment more expensive. Another disadvantage is mismanaging the debt which leads to bad effects on countries' economic growth. Moreover, tax payments on future income of countries should be paid as a cost on debt (Krugman, 1988; Cohen, 1995). Al Kharusi and Ada (2018) gathered time series data for a period of 26 years starting from year 1990 till year 2015. The authors modified a model constructed by Mbah, Agu and Umunna (2016) that includes growth rate of GDP as a dependent variable and the ratio of foreign debt to GDP as the main independent variable. Also, they included some control variables such as inflation, an indicator for labor (growth rate of population), trade to GDP ratio, an indicator for capital (gross fixed capital formation) and primary school enrolment as an indicator for human capital. In their methodology, Augmented Dickey Fuller (ADF) was used to check the stationarity of data and then an Autoregressive Distributed Lag (ADRL) was used to examine whether an existence of long run relationship among the variables occur or not. Furthermore, Error Correction Mechanism (ECM) was used to determine how Oman's economic growth was affected by using foreign debt. Finally, they concluded an existence of long run relationship among the studied variables. Moreover, ECM showed that the ratio of foreign debt to GDP adversely affected Oman's economic growth, where the economic growth declined by $0.04 \%$ as a result of increasing the foreign debt to GDP ratio by $1 \%$. The authors recommended that Oman needs foreign debt to fill the gap that emerged from decreasing the oil prices, while using this debt efficiently and with sound policies to help Oman in enhancing the performance of its economy. These results supported Mbah et al. (2016), Rais and Anwar (2012), and Rifaqat and Usman (2012).

Senadza, Fiagbe and Quartey (2018) investigated the debt-growth nexus for the Sub-Saharan countries for a period ranging from 1990 till 2013. They employed the real GDP growth rate as the dependent variable while the ratio of foreign debt to GDP, the ratio of total investment to GDP, the natural log of labor force and the exports growth rate were used as independent variables. Also, a dummy variable was used to indicate the level of income in which 1 reflects middle income and 0 reflects low income. The authors used system Generalized Methods of Moments (GMM) in their methodology. Finally, they concluded that the economic growth of the Sub-Saharan countries is negatively influenced by foreign debt at which the growth rate decreases by $0.05 \%$ when the ratio of foreign debt to GDP increases by $1 \%$. The results were the same for all countries' 
levels whether low income or middle income. In addition, the authors recommended that countries can take foreign debt but they must devote efforts to manage and pool these funds in a productive investment.

In addition, another study held by (Lin \& Sosin, 2001) focused on analyzing the relationship among using external debt and economic growth. The authors stated that some countries have the problem of insufficient domestic savings and thus they seek finance from foreign market participants' savings. These savings could be foreign debt or foreign investment. Scholars focused on foreign investment and economic growth relationship rather than foreign debt. Therefore, the authors chose to study the foreign debt-economic growth nexus. Borrowing from outside could help countries to increase investments, buy new machines, achieve technological advancements and others which help in higher production and thus higher economic growth. However, the cost of debt which is interest requires more revenues allocated to productive activities which might negatively affect economic growth. Since borrowing from outside has some benefits and some costs, so how foreign debt impacts the economic growth could not be generalized. The authors examined how the economic growth for 77 countries is affected by using external debt. They divided the sample of 77 countries into sub samples as follows; African countries, industrialized countries, Latin American countries and Asian, other non-American and other non-African countries. The study covered the period from 1970 to 1992 . Moreover, the annual growth rate was calculated for the GDP per capita to be used as the dependent variable and as an indicator for economic growth. What is more, the ratio of foreign debt to GDP was used as an independent variable and it reflected the government's obligations among the studied period. Other independent variables used were population growth rate, total investment to GDP and initial GDP per capita. Trade openness and government expenditures were used as control variables. Moreover, a dummy variable for each sub-sample was used as well. A correlation matrix was conducted to determine whether a multicollinearity problem existed or not and a regression analysis was used to reach the relationship between the variables employed in the study.

Finally, Lin and Sosin (2001) concluded that the economic growth for the whole sample (77 countries) is negatively affected by using external debt which could be supported by Siddique, Selvanathan and Selvanathan (2016). Furthermore, African countries sample showed a significant negative relationship as well. However, Latin American countries and industrialized countries' results were negative but insignificant. Asian and other countries showed an insignificant positive relationship. The authors added that foreign debt could foster economic growth if it is utilized and managed efficiently.

\section{Data and Methodology}

Section three includes the research model applied in this study with an explanation for the variables. In addition, the data collection method is clarified. Finally, this section explains the methodological techniques used to address the study's 
aim starting with descriptive statistics, unit root tests, Johansen Co-integration and then VECM.

\subsection{Research Model}

$$
\mathrm{RGDP}_{\mathrm{it}}=\beta 0_{\mathrm{it}}+\beta 1 \mathrm{TFD}_{\mathrm{it}}+\beta 2 \mathrm{TO}_{\mathrm{it}}+\beta 3 \mathrm{FD}_{\mathrm{it}}+\beta 4 \mathrm{INF}_{\mathrm{it}}+\beta 5 \mathrm{INT}_{\mathrm{it}}+\beta 6 \mathrm{EX} \text { it }+\varepsilon_{\mathrm{it}}
$$

where:

RGDP is Real Gross Domestic Product per Capita for Egypt at period t;

$\beta$ is the coefficient;

TFD is Total Foreign Debt as a Percentage of GDP for Egypt at period t;

TO is Trade Openness for Egypt at period t;

FD is Financial Development for Egypt at period t;

INF is Inflation Rate for Egypt at period t;

INT is Real Interest Rate for Egypt at period t;

Ex is Exchange Rate for Egypt at period t;

$\varepsilon$ is the error term.

\subsection{Variables' Description}

\subsubsection{Dependent Variable}

The dependent variable used in this study is Real GDP per capita (RGDP) as a measure for the Egyptian economic growth. It is calculated by the ratio of real GDP to mid-year population.

\subsubsection{Independent Variable}

Total Foreign Debt to GDP (TFD) ratio is used as the main independent variable in this study. Total foreign debt is measured by adding the long term debt which includes public, publicly guaranteed, and private nonguaranteed debt along with the short-term debt (debt with less than one year maturity) and the credit obtained from the international monetary fund. It is calculated as a percentage of GDP (Al Kharusi \& Ada, 2018; Senadza et al., 2018; Egbetunde \& Akinlo, 2015; Lin \& Sosin, 2001).

\subsubsection{Control Variables}

Control variables mean variables that are held constant in the study, but exert an effect over the results. For example, when examining the association between variable " $\mathrm{X}$ " and variable " $\mathrm{Y}$ ", the results might be spurious unless control variables are included as they affect the results as mentioned earlier (Ritzer, 2007). This study employs the following control variables; Trade Openness (TO) that is calculated by adding imports to exports as a ratio of GDP. Financial Development (FD) measured by an index originated by the International Monetary Fund (IMF). It measures how efficient, deep, stable and accessible both the financial institutions and financial markets of countries. The index was created for 183 countries. Examples for financial institutions include banks, insurance companies, mutual funds, and pension funds. While, examples for financial markets include stock market and bonds market. If depth, access and efficiency exist, 
then financial development exists as well. Depth reflects the size and liquidity of the market. Access reflects the extent to which companies and individuals can reach the financial services. Efficiency reflects the extent to which institutions offer low cost financial services and gain sustainable profits, and the level of activity in the market (Svirydzenka, 2016).

Lending rate minus inflation (Neely \& Rapach, 2008) is used as an indicator for Real Interest Rate (INT). Inflation Rate (INF) means a persistent increase in the price level (Bozkurt, 2014). It is computed as the rate of growth for the GDP implicit deflator annually which reflects the change in prices of the whole economy. Finally, Exchange Rate (EX) is the rate that is determined by the state authorities. It is measured by calculating a yearly average based on the monthly averages (domestic currency units in proportion to the U.S. dollar).

\subsection{Data Collection}

In this study, secondary time series annual data are collected from year 1980 to 2018 in Egypt. Real GDP per capita, total foreign debt, trade openness, real interest rate, inflation rate and exchange rate are collected from the database of the World Bank. While, financial development is collected from the IMF.

\subsection{Methodology}

\subsubsection{Descriptive Statistics}

Descriptive statistics is the first methodological step used in this study. It clarifies and summarizes the data by presenting the value of its mean and median, the highest and lowest values, standard deviation, and skewness and kurtosis for the studied data. Conner and Johnson (2017) explained descriptive statistics as a tool used to present and summarize the data in a way that would be understood more easily. It includes quantitative data and some other representation such as charts or graphs. On the other hand, descriptive statistics cannot be used only to reach a conclusion, but they provide a base for future analysis and investigations.

\subsubsection{Unit Root Test}

Unit root test is executed for the purpose of identifying the stationarity of the time series data before determining the likelihood of having a long run relationship between the examined variables. If the series has restricted variance, stable mean, tends to return to the equilibrium mean value and has 1 (0) which means zero order of integration, then the series is considered to be stationary. However, if the series is non-stationary which means that unstable mean and covariance exists, then it should be differenced to reach 1 (0), and in this case the series is integrated of order " $n$ " which can be shown as $\mathrm{Xt} \sim 1(\mathrm{n})$ (Awe \& Olawumi, 2012).

Augmented Dickey Fuller (ADF) and Phillips Perron (PP) are the most frequently used unit root tests and they are applied for the time series data in this study. 


\subsubsection{Johansen Co-Integration Test}

After identifying the stationarity of data by using both ADF and PP tests, the study seeks to investigate if a long run relationship among the variables exists or not. Trace and maximum eigenvalue tests are two different ratio tests proposed by Johansen $(1988,1995)$ for determining the significance of the established correlations. They are shown in the following two equations:

$$
\begin{gathered}
J_{\text {trace }}=-T \sum_{i-r+1}^{n} \ln \left(1-\lambda_{i}^{\wedge}\right) \\
J_{\max }=-T \ln \left(1-\lambda_{i}^{\wedge}\right)
\end{gathered}
$$

The sample size is reflected by $T$ and $\lambda_{i}$ refers to the th largest established correlation. The null hypothesis is of $r$ co-integrating vectors is tested against two different alternative hypothesis based on the ratio test. The trace test tests the null hypothesis against the alternative hypothesis of $\mathrm{n}$ co-integrating vectors. While, the maximum eigenvalue test tests the null hypothesis against the alternative hypothesis of $r+1$ co-integrating vectors (Johansen \& Juselius, 1990; Johansen, 1988, 1995). The following two hypotheses reflect the Johansen test:

HO. No co-integration exists between variables

H1: Variables are co-integrated.

\subsubsection{Vector Error Correction Model}

After testing for the existence of long run relationship using the Johansen co-integration test, the next step depends on if a co-integration exists or not between the examined variables. If the data is not co-integrated, then a VAR (Vector Auto Regressive) model will be used. However, if co-integration exists among the studied variables, then a VECM will be used. VECM is better as the changes in the variables in the short-run and any deviations from the long run equilibrium are adjusted (Binh, 2013). Therefore, after detecting that a long run relationship among the studied variables exists, VECM is used to investigate both the direction of the long run relationship and the properties of the short run co-integrated series.

\section{Results and Discussion}

Section four addresses both the findings and discussion for the results reached in this study. It starts with explaining the results of descriptive statistics, unit root tests (ADF and PP), followed by Johansen Co-integration and VECM.

\subsection{Descriptive Statistics}

Table 1 shows descriptive statistics' results.

Table 1 illustrates the descriptive statistics for the data used in the study. It shows that the number of observations used is 39 observation ranging from year 1980 till 2018. Egypt reached $\$ 2907.318$ as a maximum value for RGDP in 2018 after applying an action program through using a fiscal policy in 2016 (Abdou \& Zaazou, 2018). Total foreign debt in Egypt is increasing in general. The maximum 
Table 1. Descriptive statistics.

\begin{tabular}{cccccccc}
\hline & RGDP & TFD & TO & FD & IR & INF & EX \\
\hline Mean & 1960.567 & 31.20597 & 50.15642 & 0.247850 & 0.576280 & 10.89507 & 4.507983 \\
Median & 1898.636 & 26.76181 & 48.27827 & 0.248493 & 0.171498 & 11.24762 & 3.395250 \\
Maximum & 2907.318 & 59.06875 & 74.45958 & 0.451880 & 3.370865 & 24.73086 & 17.78253 \\
Minimum & 1102.308 & 15.79182 & 30.24655 & 0.149486 & -0.371351 & -2.198235 & 0.700001 \\
Std. Dev. & 541.6372 & 13.71023 & 11.26822 & 0.080835 & 0.975335 & 6.049600 & 3.931689 \\
Skewness & 0.221849 & 0.709342 & 0.425441 & 0.571463 & 1.505346 & 0.223685 & 1.902221 \\
Kurtosis & 1.715119 & 2.189256 & 2.407732 & 2.529734 & 4.259414 & 2.923242 & 7.375904 \\
Jarque-Bera & 3.002654 & 4.338706 & 1.746518 & 2.482074 & 17.30689 & 0.334803 & 54.63627 \\
Probability & 0.222834 & 0.114252 & 0.417588 & 0.289084 & 0.000175 & 0.845860 & 0.000000 \\
Sum & $76,462.13$ & 1217.033 & 1956.100 & 9.666131 & 22.47490 & 424.9076 & 175.8113 \\
Sum Sq. Dev. & $11,148,091$ & 7142.879 & 4824.968 & 0.248303 & 36.14855 & 1390.711 & 587.4109 \\
Observations & 39 & 39 & 39 & 39 & 39 & 39 & 39 \\
\hline
\end{tabular}

Source: Author's computation using E-views software version 9.

value is 59.068 as a percentage of GDP is found to be in 1987 after the oil prices crash. Trade openness as a percentage of GDP is found to be at its highest levels after engaging in the financial globalization process in 1981 with a value of $74.45 \%$. Financial development index mean is 0.24 and its standard deviation is 0.08. It increased in Egypt for the last two decades, where it reached 0.30 in 2016 compared to 0.18 in 1994 with minor fluctuations that occurred between 2001 and 2010. This pattern depended on developing the financial market in Egypt more than developing the financial institutions (Mohieldin, Hussein, \& Rostom, 2019). The maximum value for the real interest rate and inflation rate is $3.3 \%$ and $24.7 \%$ respectively for the years 1981 and 1982 with a dispersion from the mean value by 0.97 for real interest rate and 6.04 for inflation. Finally, a very large variation between the minimum and maximum values of exchange rate existed.

\subsection{Unit Root Tests Results}

Table $2 \&$ Table 3 present the ADF and PP unit root results.

As shown in the two tables (Table 2 and Table 3), all of the variables are tested both in the level and in the first difference with an intercept and an intercept with a time trend. The results show that some variables such as (RGDP, TFD, FD, IR and EX) are non-stationary at their levels, where the probability shows insignificant results. For example, the RGDP probability results for both intercept and intercept with trend are 0.98 and 0.11 respectively in ADF results (Table 2) and 0.97 for the intercept and 0.67 for the intercept with trend in PP results (Table 3). All of the variables were differenced at the 1st difference to achieve a trend stationary level, where significant results at $5 \%$ level are obtained in both unit root tests (ADF and PP). This means that the series is integrated to order 1 , which is expressed as 1 (1). 
Table 2. ADF results.

\begin{tabular}{|c|c|c|c|c|}
\hline \multicolumn{5}{|c|}{ Augmented Dickey-Fuller Unit Root Test } \\
\hline \multicolumn{5}{|c|}{ At Level } \\
\hline Variable & Intercept & Prob. & Intercept \& Trend & Prob. \\
\hline RGDP & 0.522876 & 0.9852 & -3.146117 & 0.1115 \\
\hline TFD & -0.94802 & 0.7616 & 1.280142 & 0.9999 \\
\hline TO & -4.233078 & $0.0022^{*}$ & -4.411566 & $0.0068^{\star}$ \\
\hline FD & -1.337935 & 0.6019 & -1.66881 & 0.7455 \\
\hline IR & -5.009181 & $0.0002^{*}$ & -5.254071 & $0.0006^{*}$ \\
\hline INF & -4.289797 & $0.0016^{*}$ & -4.203968 & $0.0104^{\star}$ \\
\hline EX & 1.952989 & 0.9998 & 0.225796 & 0.9974 \\
\hline \multicolumn{5}{|c|}{ At 1st Difference } \\
\hline RGDP & -3.553275 & $0.0122^{*}$ & -3.592479 & $0.0451^{\star}$ \\
\hline TFD & -4.078261 & $0.0030^{\star}$ & -4.165743 & $0.0116^{\star}$ \\
\hline TO & -4.706801 & $0.0005^{*}$ & -4.76209 & $0.0025^{*}$ \\
\hline FD & -4.82033 & $0.0004^{*}$ & -4.759345 & $0.0025^{\star}$ \\
\hline IR & -8.964744 & $0.0000^{*}$ & -8.931981 & $0.0000^{*}$ \\
\hline INF & -10.94876 & $0.0000^{*}$ & -10.77087 & $0.0000^{*}$ \\
\hline EX & -4.681791 & $0.0006^{*}$ & -5.087742 & $0.0011^{*}$ \\
\hline
\end{tabular}

${ }^{*}$ Results are significant at 5\% level. Source: Author's computation using E-views software version 9 .

Table 3. PP results.

\begin{tabular}{ccccc}
\hline \multicolumn{5}{c}{ Phillips Perron Unit Root Test } \\
\hline Variable & Intercept & At Level & \\
\hline RGDP & 0.275361 & 0.9738 & -1.81630 & 0.6770 \\
TFD & -1.180855 & 0.6727 & -0.945547 & 0.9398 \\
TO & -2.733641 & 0.0778 & -2.591570 & 0.2860 \\
FD & -1.483805 & 0.5309 & -2.103307 & 0.5275 \\
IR & -1.966246 & 0.2999 & -1.877135 & 0.6466 \\
INF & -4.429168 & $0.0011^{*}$ & -4.356661 & $0.0071^{*}$ \\
EX & 2.027548 & 0.9998 & 0.225796 & 0.9974 \\
\hline RGDP & -3.167185 & $0.0302^{*}$ & -3.183093 & 0.1034 \\
TFD & -4.078261 & $0.0030^{*}$ & -4.114356 & $0.0132^{*}$ \\
TO & -4.687190 & $0.0006^{*}$ & -4.802858 & $0.0023^{*}$ \\
FD & -4.818313 & $0.0004^{*}$ & -4.758557 & $0.0025^{*}$ \\
IR & -6.598021 & $0.0000^{*}$ & -6.493151 & $0.0000^{*}$ \\
INF & -11.63220 & $0.0000^{*}$ & -11.46865 & $0.0000^{*}$ \\
EX & -4.684563 & $0.0006^{*}$ & -5.089357 & $0.0011^{*}$ \\
\hline
\end{tabular}

${ }^{\star}$ Results are significant at 5\% level. Source: Author's computation using E-views software version 9. 


\subsection{Johansen Co-Integration}

Johansen Cointegration results are shown in Table 4.

The results of Table 4 indicate a rejection for the null hypothesis, meaning that a long run relationship among the studied variables exists. The trace value (215.9039) is higher than the critical value (125.6154) at 5\%. Moreover, the maximum eigenvalue (100.6330) is higher than the critical value $(46.23142)$ at $5 \%$ as well. The results can be supported by (Al Kharusi \& Ada, 2018; Mbah et al., 2016; Egbetunde \& Akinlo, 2015; Rais \& Anwar, 2012).

\subsection{Vector Error Correction Model}

After detecting the existence of long run relationship between the studied variables, VECM is computed to detect the direction of this relationship as in $\mathrm{Ta}$ ble 5 .

Table 4. Johansen co-integration results.

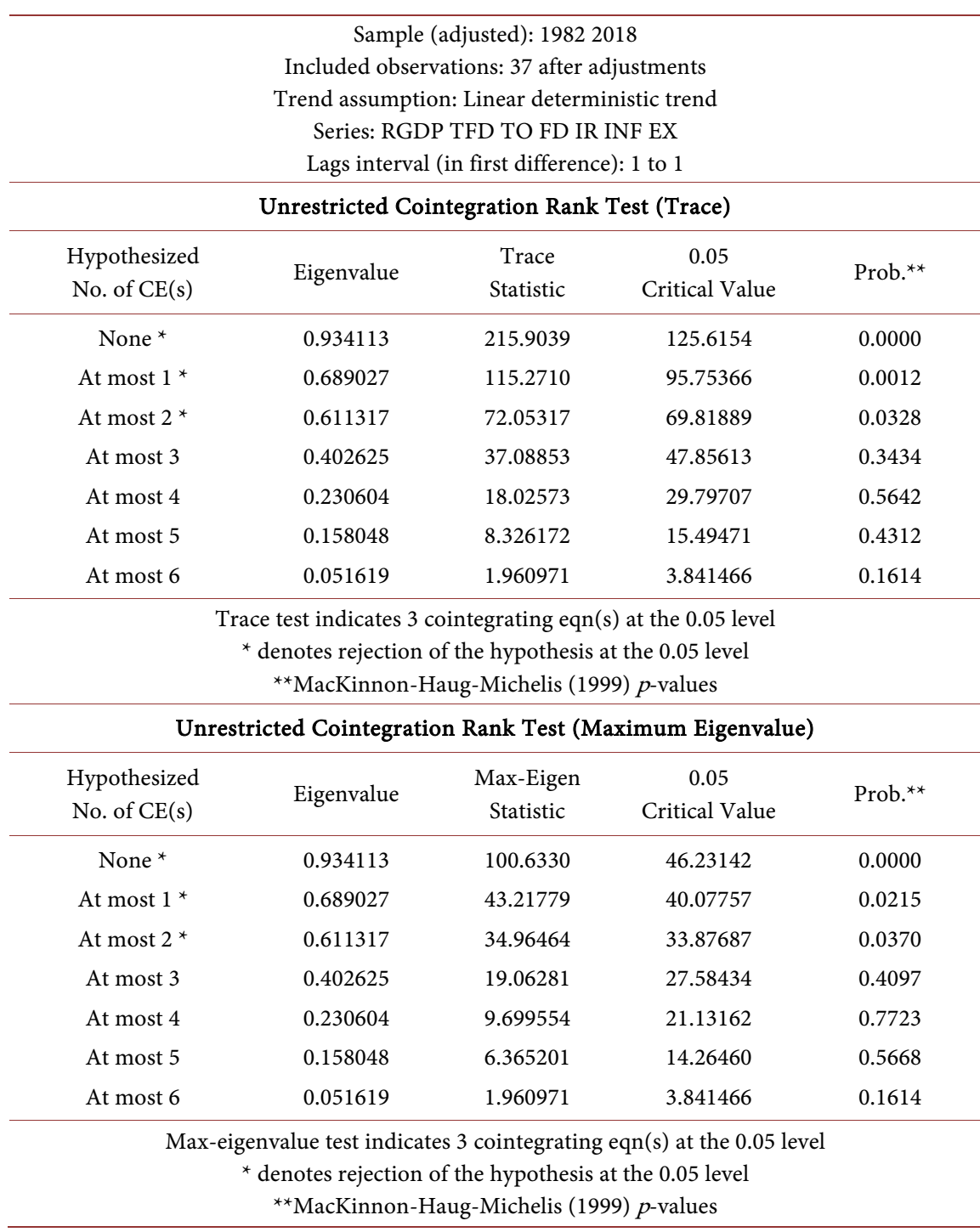

Source: Author's computation using E-views software version 9. 
VECM results shown in Table 5 reflect a significant long run negative impact of total foreign debt as a percentage of GDP on the Egyptian economic growth, which can be supported by (Shkolnyk \& Koilo, 2018; Senadza et al., 2018; Mbah et al., 2016; Siddique et al., 2016; Rais \& Anwar, 2012; Rifaqat \& Usman, 2012; Lin \& Sosin, 2001).

Table 5. VECM results.

\begin{tabular}{|c|c|}
\hline \multicolumn{2}{|c|}{$\begin{array}{l}\text { Vector Error Correction Estimates } \\
\text { Sample (adjusted): } 19832018 \\
\text { Included observations: } 36 \text { after adjustments } \\
\text { Standard errors in ( ) \& t-statistics in [ ] }\end{array}$} \\
\hline Cointegrating Eq: & CointEq1 \\
\hline RGDP $(-1)$ & 1.000000 \\
\hline $\operatorname{TFD}(-1)$ & $\begin{array}{l}-12.36993 \\
(4.62621) \\
{[-2.67388]}\end{array}$ \\
\hline $\mathrm{TO}(-1)$ & $\begin{array}{l}8.516119 \\
(2.07410) \\
{[4.10594]}\end{array}$ \\
\hline $\mathrm{FD}(-1)$ & $\begin{array}{l}-4991.527 \\
(383.197) \\
{[-13.0260]}\end{array}$ \\
\hline $\operatorname{IR}(-1)$ & $\begin{array}{r}-344.3428 \\
(44.9367) \\
{[-7.66284]}\end{array}$ \\
\hline $\operatorname{INF}(-1)$ & $\begin{array}{l}-81.33911 \\
(10.4508) \\
{[-7.78303]}\end{array}$ \\
\hline $\operatorname{EX}(-1)$ & $\begin{array}{r}-160.8792 \\
(26.2505) \\
{[-6.12861]}\end{array}$ \\
\hline $\mathrm{C}$ & 1035.739 \\
\hline Error Correction: & $\mathrm{D}$ (RGDP) \\
\hline CointEq1 & $\begin{array}{r}-0.042702 \\
(0.03696) \\
{[-1.15528]}\end{array}$ \\
\hline $\mathrm{D}(\mathrm{TFD}(-1))$ & $\begin{array}{l}2.249250 \\
(1.16162) \\
{[1.93630]}\end{array}$ \\
\hline $\mathrm{D}(\mathrm{TFD}(-2))$ & $\begin{array}{l}0.344874 \\
(1.39143) \\
{[0.24786]}\end{array}$ \\
\hline $\mathrm{C}$ & $\begin{array}{l}42.66603 \\
(12.7044) \\
{[3.35837]}\end{array}$ \\
\hline
\end{tabular}




\begin{tabular}{cc}
\hline R-squared & 0.765441 \\
Adj. R-squared & 0.589522 \\
Sum sq. resids & 9608.624 \\
S.E. equation & 21.91874 \\
F-statistic & 4.351097 \\
Log likelihood & -151.6459 \\
Akaike AIC & 9.313663 \\
Schwarz SC & 10.01745 \\
Mean dependent & 46.40181 \\
S.D. dependent & 34.21139 \\
\hline Determinant resid covariance (dof adj.) & 53.38886 \\
Determinant resid covariance & 0.872053 \\
Log likelihood & -355.1082 \\
Akaike information criterion & 26.33935 \\
Schwarz criterion & 31.57376 \\
\hline
\end{tabular}

Source: Author's computation using E-views software version 9.

Al Kharusi and Ada (2018) reached the same conclusion and argued that sometimes countries mismanage the usage of debt which in turn affects their economic growth negatively. The results could be supported also by Abiad and Ostry (2005) who argued that on the long run, building up more debt would destroy the countries' economic growth. In addition, many other reasons are mentioned above in the literature review section behind the adverse effect of the total foreign debt on countries' economic growth such as: using debt might discourage investment (Borensztein, 1990). Feldstein (1986) clarified the negative effect by stating that governments are forced to increase taxes on the private sector with the aim of financing the obligations needed for debt. As a result, a reduction in the level of return on investment occurs and thus both investment and economic growth are decreased. Furthermore, governments focus on repaying the debt which adversely affects their expenditures on public services such as health and education. In addition, domestic currency devaluation used to encourage the flow of foreign exchange into the economy (Serieux \& Yiagadeesen, 2001), both production and investment are adversely influenced by using foreign debt (Pattillo et al., 2003), and the burden of loan repayment when it exceeds a specific level (Pattillo et al., 2002).

On the other hand, the results show an insignificant impact of total foreign debt as a percentage of GDP on the Egyptian economic growth in the short run, which can be supported by (Tchereni, Sekhampu, \& Ndovi, 2013; Ogunmuyiwa, 2011). Cuestas, Gil-Alana and Staehr (2014) explained that total debt affects countries' economic growth significantly only when it increases above a specific value. Smyth and Hsing (1995) concluded that as long as the ratio of debt to GDP is below $38.4 \%$, then the economic growth would not be adversely affected. Furthermore, Reinhart, Reinhart and Rogoff (2012) stated that if the level of total debt is below $90 \%$ of the GDP, then it would not exert any effect on the eco- 
nomic growth of both developing and developed countries. On the other hand, if the total foreign debt to GDP ratio is approximately around 60\%, then the economic growth of developing countries would be negatively impacted. Pegkas (2018) reached the same conclusion where a negative long run relationship among using debt and economic growth exists, but it depends on the level of debt. The author studied this effect in Greece where the total debt affected the economic growth significantly when the debt to GDP ratio became $105 \%$. In addition, the author argued that accumulated debt for many years strengthens the effect on the economic growth which can support the results of this study.

The control variables' results show that trade openness positively affects the economic growth of Egypt, which can be supported by (Turan \& Seni, 2014; Vamvakidis, 2002). Dao (2014) reached the same conclusion and explained it by stating that as long as the country decreases the restrictions and thus opens up to more trade, it will exert more effort on Research and Development (R\&D) which will lead to higher production and profit margins that is reflected in their economic growth levels. Financial development results show a significant negative impact on the Egyptian economic growth, which is supported by (Law \& Singh, 2014; Hye \& Islam, 2013; Hye, 2011). Financial depth is used to measure financial development, which can be represented by credit to GDP ratio. High credit to GDP ratio might reflect financial fragility ${ }^{1}$ and thus uncertainty which deters economic growth (Wachtel, 2011). Bezemer, Grydaki and Zhang (2014) added that high levels of credit to GDP ratio adversely affect the economic growth as it causes higher volatility, less investment and might cause financial crises. In addition, De Gregorio and Guidotti (1995) stated that financial development requires liberalizing the financial system. When the process of liberalization is carried out under a poor regulatory system, then its effect will be negative on the economy.

Regarding real interest rate, the results show that it significantly impacts the economic growth of Egypt negatively, which can be supported by (Di Giovanni \& Shambaugh, 2008; Guseh \& Oritsejafor, 2007). Hatmanu, Cautisanu and Ifrim (2020) reached the same conclusion and explained the reason behind this inverse relationship by stating that the lower the lending rate, the higher will be the incentives of taking loan with lower cost which will increase investment and thus reflected in higher economic growth. This explanation could be supported by (Akinwale, 2018) as well. Inflation rate results show that it has a significant adverse impact on the Egyptian economic growth, which can be supported by (Švigir \& Miloš, 2017; Kasidi \& Mwakanemela, 2013; Quartey, 2010; Berument, Inamlik, \& Olgun, 2008). Boyd and Champ (2006) stated that inflation causes reduction in savings and increases borrowing which causes an increase in the nominal interest rate. Higher interest rates mean that investments decrease and thus lower economic growth. Barro (1995) and Fischer (1993) had also reached the same conclusion and stated that as inflation increases, investments and productivity decreases which reflects deterioration in countries' economic ${ }^{1}$ Crockett (1995) defined financial fragility as the level of debt that increases the economic sensitivity towards any shocks and thus adversely affects the economic growth. 
growth.

The last control variable which is exchange rate exerts a significant negative impact on the economic growth of Egypt, which is supported by (Obansa, Okoroafor, Aluko, \& Millicent, 2013; Ahmad, Ahmad, \& Ali, 2013; Younus \& Chowdhury, 2006). Razzaque, Bidisha and Khondker (2017) reached the same conclusion and stated that as long as the value of the local currency depreciates, the economic growth of the country is fostered. The authors clarified this relationship through two main reasons; the first is that depreciated currencies enhance the competitiveness globally and thus increases exports, the second is that depreciated currencies shift the demand towards domestic goods. This could be supported by (Karahan, 2020) as well.

The results show that $\mathrm{R}$-squared is $76.5 \%$ which means that the explanatory variables explain $76.5 \%$ of the variations in the dependent variable (economic growth).

\section{Conclusion and Recommendations}

Developing countries are continuously trying to exert efforts towards boosting their economic growth levels. However, due to the insufficient capital needed to invest domestically, developing countries are forced to borrow from external sources. By utilizing the external debt towards effective projects, economic growth could be achieved (Todaro \& Smith, 2006). For developing countries, foreign debt is considered to be a very important source of income, but the burden that results from it might cause major problems for them (Forgha et al., 2014).

Since a debate exists for how foreign debt impacts countries' economic growth, as it has benefits as well as costs, then this study aims to investigate the impact of total foreign debt on the Egyptian economic growth for 39 years ranging from 1980 till 2018. It conducts first descriptive statistics to summarize the data. After that, the study applies both ADF and PP to find out the stationarity of the examined data and reached that they are stationary at the first difference. Johansen co-integration is used which shows an existence of long run relationship among the studied variables. Finally, VECM is carried out to detect the direction of the long run relationship and the adjustments of the short run. The results show that TFD as a percentage of GDP exerts a significant negative impact on the Egyptian economic growth in the long run and an insignificant impact in the short run. Mismanagement of debt (Al Kharusi \& Ada, 2018), debt overhang (Borensztein, 1990), crowding effect, liquidity constraint (Serieux \& Yiagadeesen, 2001), direct effect of debt (Pattillo et al., 2003), and Debt Laffer Curve Theory (Pattillo et al., 2002) are reasons behind the negative impact of foreign debt on economic growth.

Furthermore, the results for the control variables show that the Egyptian economic growth is positively impacted by trade openness, while all of the other control variables (financial development, real interest rate, inflation rate and 
exchange rate) impact the Egyptian economic growth negatively.

Poor economic policies are one of the major reasons behind high levels of debt (Easterly, 2002). However, due to the adverse effects of foreign debt on the Egyptian economy, then it is recommended that Egypt should focus on reducing the level of external debt in order to be able to boost its level of economic growth. However, if foreign debt must be acquired, then government should focus on spending it on productive liquidating projects (Gabriel \& Ogiemudia, 2013). Muhanji and Ojah (2011) recommended many ways through which the debt could be decreased and managed properly. Firstly, developing the governance infrastructure (voice and accountability, government effectiveness, political stability, regulatory quality, rule of law and control of corruption $)^{2}$ that was developed by Kaufmann et al. (2010) is one of the ways that would extremely help developing countries to decrease their level of external debt. Secondly, efforts exerted towards increasing exports and stabilizing the political environment would increase the amount of liquidity in the economy and thus decrease the need of foreign debt. The existence of effective institutions has a significant role in boosting the level of exports and decreasing imports and thus reducing the amount of external debt needed. Finally, imports of intermediate goods should increase for investment purposes, but consumption goods' imports should be decreased.

\section{Conflicts of Interest}

The authors declare no conflicts of interest regarding the publication of this paper.

\section{References}

Abdou, D. M., \& Zaazou Z. (2018). Impact of the Socio-Economic Situation Post the Egyptian Revolution (2011). International Journal of Service Science, Management and Engineering, 5, 65-74.

Abiad, M. A., \& Ostry, M. J. D. (2005). Primary Surpluses and Sustainable Debt Levels in Emerging Market Countries. International Monetary Fund.

Ahmad, A., Ahmad, N., \& Ali, S. (2013). Exchange Rate and Economic Growth in Pakis$\tan$ (1975-2011). Journal of Basic and Applied Scientific Research, 3, 740-746.

Akinwale, S. O. (2018). Bank Lending Rate and Economic Growth: Evidence from Nigeria. International Journal of Academic Research in Economics and Management Sciences, 7, 111-122. https://doi.org/10.6007/IJAREMS/v7-i3/4440

${ }^{2}$ Kaufmann, Kraay and Mastruzzi defined the six indicators where; rule of law is the level of adherence to rules by the citizens, the enforcement of contracts' quality, property rights and others; voice and accountability is the level of citizens' participation in the process of governments' elections, their freedom to express their opinions and others; control of corruption is the level of using public power to get private benefits; regulatory quality is the level to which the government is able to apply strong and efficient policies and regulates the economy which helps in developing the private sector; government effectiveness represents whether the governmental services, constructing and executing of policies are of high quality or not and whether the government is credible in applying the formulated policies or not; political stability is the probability of having instability as a result of having violent crimes or terrorist attacks. 
Al Kharusi, S., \& Ada, M. (2018). External Debt and Economic Growth: The Case of Emerging Economy. Journal of Economic Integration, 33, 1141-1157. https://doi.org/10.11130/jei.2018.33.1.1141

Alissa, S. (2007). The Political Economy of Reform in Egypt: Understanding the Role of Institutions. Carnegie Papers, No. 5, 1-27.

Awe, A. A., \& Olawumi, O. R. (2012). Determinant of Income Distribution in the Nigerian Economy: 1997-2005. International Business and Management, 15, 126-137.

Babu, J. O., Kiprop, S., Kalio, A. M., \& Gisore, M. (2015). Effect of Domestic Debt on Economic Growth in the East African Community. American Journal of Research Communication, 3, 73-95.

Barro, R. J. (1995). Inflation and Economic Growth. NBER Working Paper No. 5326. https://doi.org/10.3386/w5326

Berument, H., Inamlik, A., \& Olgun, H. (2008). Inflation and Growth: Positive or Negative Relationship? Journal of Applied Sciences, 8, 192-204.

https://doi.org/10.3923/jas.2008.192.204

Bezemer, D., Grydaki, M., \& Zhang, L. (2014). Is Financial Development Bad for Growth? University of Groningen.

Binh, P. T. (2013). Unit Root Tests, Cointegration, ECM, VECM, and Causality Models. Topics in Time Series Econometrics, 1-157.

Borensztein, E. (1990). Debt Overhang, Credit Rationing and Investment. Journal of Development Economics, 32, 315-335. https://doi.org/10.1016/0304-3878(90)90041-9

Boyd, J. H., \& Champ, B. A. (2006). Inflation, Banking, and Economic Growth (pp. 1-4). Federal Reserve Bank of Cleveland.

Bozkurt, C. (2014). Money, Inflation and Growth Relationship: The Turkish Case. International Journal of Economics and Financial Issues, 4, 309-322.

Brkić, M. (2021). Costs and Benefits of Government Borrowing in Foreign Currency: Is It A Major Source of Risk for EU Member States Outside the Euro? Public Sector Economics, 45, 63-91. https://doi.org/10.3326/pse.45.1.2

Central Bank of Egypt (CBE) (2003). Central Bank of Egypt (CBE) Annual Report. https://www.cbe.org.eg/en/EconomicResearch/Publications/Pages/AnnualReport.aspx

Central Bank of Egypt (CBE) (2018). External Position of the Egyptian Economy. FY 2017/2018, 66.

https://www.cbe.org.eg/en/EconomicResearch/Publications/Pages/ExternalPosition.aspx

Central Bank of Egypt (CBE) (2019). External Position of the Egyptian Economy. FY 2018/2019, 66.

https://www.cbe.org.eg/en/EconomicResearch/Publications/Pages/ExternalPosition.aspx

Claessens, S., Detragiache, E., Kanbur, R., \& Wickham, P. (1996). Analytical Aspects of the Debt Problems of Heavily Indebted Poor Countries. World Bank Policy Research Working Paper Series, No. 1618.

Cohen, D. (1995). Large External Debt and (Slow) Large External Debt and (Slow) Domestic Growth a Theoretical Analysis. Journal of Economic Dynamics and Control, 19, 1141-1163. https://doi.org/10.1016/0165-1889(94)00822-Y

Conner, B., \& Johnson, E. (2017). Descriptive Statistics. American Nurse Today, 12, 52-55.

Crockett, A. D. (1995). Financial Fragility: Sources, Prevention, and Treatment. In H. A. Benink (Eds), Coping with Financial Fragility and Systemic Risk (pp. 267-277). Springer. https://doi.org/10.1007/978-1-4757-2373-1_22 
Cuestas, J. C., Gil-Alana, L. A., \& Staehr, K. (2014). Government Debt Dynamics and the Global Financial Crisis: Has Anything Changed in the EA12? Economics Letters, 124, 64-66. https://doi.org/10.1016/j.econlet.2014.04.014

Dao, A. (2014). Trade Openness and Economic Growth. Mark A. Israel '91 Endowed Summer Research Fund in Economics, 2, 1-29.

De Gregorio, J., \& Guidotti, P. (1995). Financial Development and Economic Growth. World Development, 23, 433-448. https://doi.org/10.1016/0305-750X(94)00132-I

Di Giovanni, J., \& Shambaugh, J. (2008). The Impact of Foreign Interest Rates on the Economy: The Role of the Exchange Rate Regime. Journal of International Economics, 74, 341-361. https://doi.org/10.1016/j.jinteco.2007.09.002

Easterly, W. (2002). How Did Heavily Indebted Poor Countries Become Heavily Indebted? Reviewing Two Decades of Debt Relief. World Development, 30, 1677-1696. https://doi.org/10.1016/S0305-750X(02)00073-6

Egbetunde, T., \& Akinlo, A. (2015). Financial Globalization and Economic Growth in Sub-Saharan Africa: Evidence from Panel Cointegration Tests. African Development Review, 27, 187-198. https://doi.org/10.1111/1467-8268.12140

Favaro, E., Garrido, L., \& Stucka, T. (2009). The Global Crisis and the Egyptian Economy, 2. Macro Policy Notes, MENA Region, World Bank.

Feldstein, M. S. (1986). Budget Deficits, Tax Rules and Real Interest Rates. NBER Working Paper No. 1970. https://doi.org/10.3386/w1970

Fischer, S. (1993). The Role of Macroeconomic Factors in Growth. NBER Working Paper, No. 4565. https://doi.org/10.3386/w4565

Forgha, N., Mbella, M., \& Ngangnchi, F. (2014). External Debt, Domestic Investment and Economic Growth in Cameroon-A System Estimation Approach. Journal of Economic Bibliography, 1, 3-16.

Gabriel, M., \& Ogiemudia, A. O. (2013). Foreign Debt Management and the Development of Nigeria Economy. Review of Economics \& Finance, 3, 99-109.

Guseh, S., \& Oritsejafor, E. (2007). Government Size, Political Freedom and Economic Growth in Nigeria, 1960-2000. Journal of Third World Studies, 24, 139-165.

Hanafy, S. (2015). Patterns of Foreign Direct Investment in Egypt-Descriptive Insights from a Novel Panel Dataset at the Governorate Level. MAGKS Joint Discussion Paper Series in Economics, No. 12-2015, Philipps-Universität Marburg.

Hatmanu, M., Cautisanu, C., \& Ifrim, M. (2020). The Impact of Interest Rate, Exchange Rate and European Business Climate on Economic Growth in Romania: An ARDL Approach with Structural Breaks. Sustainability, 12, 2798.

https://doi.org/10.3390/su12072798

Hye, Q. (2011). Financial Development Index and Economic Growth: Empirical Evidence from India. The Journal of Risk Finance, 12, 98-111. https://doi.org/10.1108/15265941111112820

Hye, Q., \& Islam, F. (2013). Does Financial Development hamper Economic Growth: Empirical Evidence from Bangladesh. Journal of Business Economics and Management, 14, 558-582. https://doi.org/10.3846/16111699.2012.654813

Johansen, S. (1988). Statistical Analysis of Cointegration Vectors. Journal of Economic Dynamics and Control, 12, 231-254. https://doi.org/10.1016/0165-1889(88)90041-3

Johansen, S. (1995). Likelihood-Based Inference in Cointegrated Vector Autoregressive Models. Oxford University Press. https://doi.org/10.1093/0198774508.001.0001

Johansen, S., \& Juselius, K. (1990). Maximum Likelihood Estimation and Inference on Cointegration with Application to the Demand for Money. Oxford Bulletin of Eco- 
nomics and Statistics, 52, 169-210.

https://doi.org/10.1111/j.1468-0084.1990.mp52002003.x

Karahan, Ö. (2020). Influence of Exchange Rate on the Economic Growth in the Turkish Economy. Financial Assets and Investing, 11, 21-34.

https://doi.org/10.5817/FAI2020-1-2

Kasidi, F., \& Mwakanemela, K. (2013). Impact of Inflation on Economic Growth: A Case Study of Tanzania. Asian Journal of Empirical Research, 3, 363-380. https://doi.org/10.6007/IJAREMS/v3-i5/1198

Kaufmann, D., Kraay, A., \& Mastruzzi, M. (2010). The Worldwide Governance Indicators: Methodology and Analytical Issues. World Bank Working Paper.

Krugman, P. (1988). Financing vs. Forgiving a Debt Overhang. Journal of Development Economics, 29, 253-268. https://doi.org/10.1016/0304-3878(88)90044-2

Law, S., \& Singh, N. (2014). Does Too Much Finance Harm Economic Growth? Journal of Banking and Finance, 41, 36-44. https://doi.org/10.1016/j.jbankfin.2013.12.020

Lin, S., \& Sosin, K. (2001). Foreign Debt and Economic Growth. Economics of Transition, 9, 635-655. https://doi.org/10.1111/1468-0351.00092

Mbah, S. A., Agu, O. C., \& Umunna, G. (2016). Impact of External Debt on Economic Growth in Nigeria: An ARDL Bound Testing Approach. Journal of Economics and Sustainable Development, 7, 16-26.

Mohieldin, M., Hussein, K., \& Rostom, A. (2019). On Financial Development and Economic Growth in Egypt. Journal of Humanities and Applied Social Sciences, 1, 70-86. https://doi.org/10.1108/JHASS-08-2019-0027

Muhanji, S., \& Ojah, K. (2011). Management and Sustainability of External Debt: A Focus on the Emerging Economies of Africa. Review of Development Finance, 1, 184-206. https://doi.org/10.1016/j.rdf.2011.09.001

Neely, C., \& Rapach, D. (2008). Real Interest Rate Persistence: Evidence and Implications. Economic Review: Federal Reserve Bank of St. Louis, Working Paper Series. https://doi.org/10.20955/wp.2008.018

Obansa, S. A. J., Okoroafor, O. K. D., Aluko, O. O., \& Millicent, E. (2013). Perceived Relationship between Exchange Rate, Interest Rate and Economic Growth in Nigeria: 1970-2010. American Journal of Humanities and Social Sciences, 1, 116-124. https://doi.org/10.11634/232907811301374

Ogunmuyiwa, M. S. (2011). Does External Debt Promote Economic Growth? Journal of Economic Theory, 3, 29-35.

Osuagwu, C., \& Orbunde, E. (2015). The Impact of Foreign Debt on Developing Nations: A Case Study of Its Effects on Nigerian Economy. Journal of Educational Policy and Entrepreneurial Research, 2, 145-159.

Pattillo, C., Poirson H., \& Ricci, L. (2002). External Debt and Growth. IMF Working Paper 02/69, 1-47. https://doi.org/10.5089/9781451849073.001

Pattillo, C., Poirson, H., Ricci, L., Kraay, A., \& Rigobon, R. (2003). Through What Channels Does External Debt Affect Growth? In Brooking Trade Forum (pp. 229-277). Brookings Institution Press. https://doi.org/10.1353/btf.2004.0013

Pegkas, P. (2018). The Effect of Government Debt and Other Determinants on Economic Growth: The Greek Experience. Economies, 6, 10.

https://doi.org/10.3390/economies6010010

Presbitero, A. F. (2012). Total Public Debt and Growth in Developing Countries. The European Journal of Development Research, 24, 606-626.

https://doi.org/10.1057/ejdr.2011.62 
Quartey, P. (2010). Price Stability and the Growth Maximizing Rate of Inflation for Ghana. Modern Economy, 1, 180-194. https://doi.org/10.4236/me.2010.13021

Rais, S. I., \& Anwar, T. (2012). Public Debt and Economic Growth in Pakistan: A Time Series Analysis from 1972 to 2010. Academic Research International, 2, 535-544.

Razzaque, M. A., Bidisha, S., \& Khondker, B. (2017). Exchange Rate and Economic Growth: An Empirical Assessment for Bangladesh. Journal of South Asian Development, 12, 42-64. https://doi.org/10.1177/0973174117702712

Reinhart, C. M., Reinhart, V. R., \& Rogoff, K. S. (2012). Public Debt Overhangs: Advanced-Economy Episodes Since 1800. Journal of Economic Perspectives, 26, 69-86. https://doi.org/10.1257/jep.26.3.69

Rifaqat, A., \& Usman, M. (2012). External Debt Accumulation and Its Impact on Economic Growth in Pakistan. The Pakistan Development Review, 51, 79-96. https://doi.org/10.30541/v51i4IIpp.79-96

Ritzer, G. (Ed.) (2007). The Blackwell Encyclopedia of Sociology (Vol. 1479). Blackwell Publishing. https://doi.org/10.1111/b.9781405124331.2007.00001.x

Saylor, R., \& Wheeler, N. (2017). Paying for War and Building States: The Coalitional Politics of Debt Servicing and Tax Institutions. World Politics, 69, 366-408. https://doi.org/10.1017/S0043887116000319

Senadza, B., Fiagbe, A., \& Quartey, P. (2018). The Effect of External Debt on Economic Growth in Sub-Saharan Africa. International Journal of Business and Economic Sciences Applied Research, 11, 61-69.

Serieux, J., \& Yiagadeesen, S. (2001). The Debt Service Burden and Growth: Evidence from Low Income Countries. The North-South Institute.

Shkolnyk, I., \& Koilo, V. (2018). The Relationship between External Debt and Economic Growth: Empirical Evidence from Ukraine and Other Emerging Economies. Investment Management and Financial Innovations, 15, 387-400. https://doi.org/10.21511/imfi.15(1).2018.32

Siddique, A., Selvanathan, E. A., \& Selvanathan, S. (2016). The Impact of External Debt on Growth: Evidence from Highly Indebted Poor Countries. Journal of Policy Modeling, 38, 874-894. https://doi.org/10.1016/j.jpolmod.2016.03.011

Smyth, D. J., \& Hsing, Y. (1995). In Search of an Optimal Debt Ratio for Economic Growth. Contemporary Economic Policy, 13, 51-59. https://doi.org/10.1111/j.1465-7287.1995.tb00731.x

Švigir, M., \& Miloš, J. (2017). Relationship between Inflation and Economic Growth; Comparative Experience of Italy and Austria. FIP-Financije i Pravo, 5, 91-101.

Svirydzenka, K. (2016). Introducing a New Broad-Based Index of Financial Development. IMF Working Paper 16/5. https://doi.org/10.5089/9781513583709.001

Tchereni, B., Sekhampu, T. J., \& Ndovi, R. F. (2013). The Impact of Foreign Debt on the Period 1990-2012. Economics \& Sociology, 8, 246-257.

Todaro, P. M., \& Smith, S. C. (2006). Economic Development (9th ed.). Pearson Education.

Turan, G., \& Seni, D. (2014). The Effect of Trade Openness on Economic Growth: Albanian Case. Academic Journal of Interdisciplinary Studies, 3, 193-200. https://doi.org/10.5901/ajis.2014.v3n3p193

Vamvakidis, A. (2002). How Robust is the Growth-Openness Connection? Historical Evidence. Journal of Economic Growth, 7, 57-80.

https://doi.org/10.1023/A:1013418610712

Wachtel, P. (2011). The Evolution of the Finance Growth Nexus. Comparative Economic 
A. Safwat et al.

Studies, 53, 475-488. https://doi.org/10.1057/ces.2011.16

Weiss, M. (2007). Iraq's Debt Relief: Procedure and Potential Implications for International Debt Relief. Congressional Research Service Report for Congress.

Younus, S., \& Chowdhury, M. I. (2006). An Analysis of Bangladesh's Transition to Flexible Exchange Rate Regime. Working Paper Series: WP 0706, Bangladesh Bank. 